\title{
解放後本院實驗生物研究所植物生理 研究室的作物春化試驗工作
}

植物生理研究屴 多年來的工作, 都是在探討 微量元素、生長素等對於植物生長的閶係。解放之

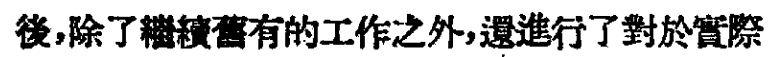
有關的新工作。

從一九四九年十月起，我僴集合了對於李森 科的春化法有興㙘的同事, 去检查我門能够找得 到的文缺, 每天下午來一個小組討論, 䍌於春化法 過去的研究，做了较詳細的學習和討論。這樣一直 到今年三月才告一段落。在小組討論的時候, 我們 跣時進行着試驗。經過了春化處理的胡莱朖、大 蒜、油荣, 在去年十一、十二月間都已經種下。接着 我們及着手了小麥的春化處理。但在上海, 院裹踓 然有些空地，可以利用。但根振我們過去的經驗， 小㐘試驗不能在那襄進行; 都市裹的麻隹太多, 對

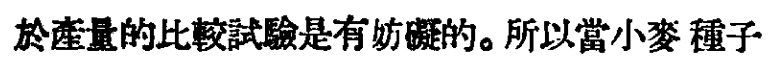

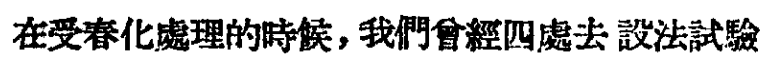

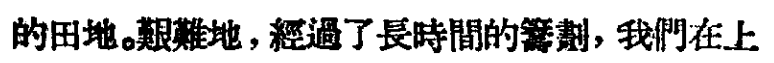

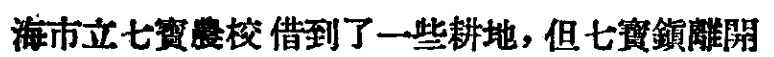
我鬥研究空相當遼。今年三月間,我們已在那赛種 下了第一批春化小麥。在罩倜試驗裹，我們想找出 所用的那種小娄，春化期究密有多少日子。以後， 我們經常去做分期播種試驗; 每隔兩星期去播種 一次。想去找出春化小梦最適宜的播種期, 和是不
是經過春化的小麥, 不諭在什应時候播種下步, 都 能触開花結盗的。

最近,油策的開花期已過，根據我們的觀祭，

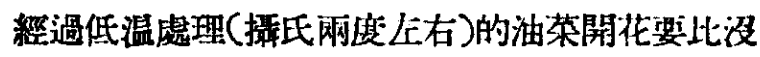
有經過處理的提早十天以上。这部分工作，我們造

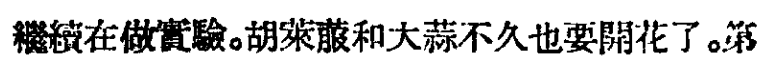
一一播種的春化小桨,已經出節。

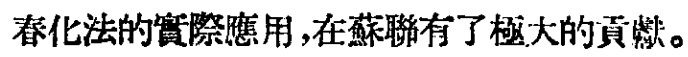
不但改變了植物播種的季節, 撺大了耕作的地彄,

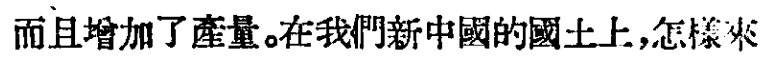
增拁我們的糧食，李森科的春化法 是應融可以採 用的。但在實際應用之前，一定要先去等悉造些經 過處理後的農作物的生長情况, 先去了解天然環 境對於逜些作物的影響。明瞭了這些事情, 才能把

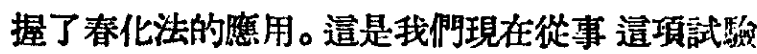
的原因。還有感什麼經過了春化之後的植物,改變

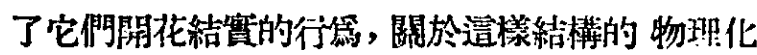

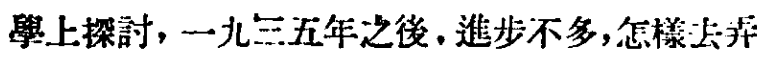
明白這程機構也是我們要努力研究的。將來的汁 劃，我們生理䂯究空的同志們，要在春化細胞及凑 化植物的物理化學的變化上，加以探究。同時本所 細胞遺傅研究室的同人. 已正在着手㷋染色法去 觀察龺化細胞和未經處理細胞的異闹。(倪晋川)

\section{(上接第113面)}

(1)原子核的質量, 牛徑, 與作用力的性質

$$
\text { (錢三强軹) }
$$

(2)原子核結合能量的牛經驗公式。( 錢三强

講)

（3)量子力舅的基本概念。(彭桓武講)

(4)量子力㦛中開於“自旋”的理諭。(彭佰武 覇)

(5)原子核的“磁矩测)定法的最近發展。(陸朝 落靖)

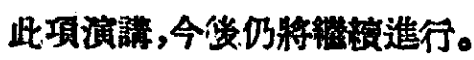

\section{（四）編譯部問}

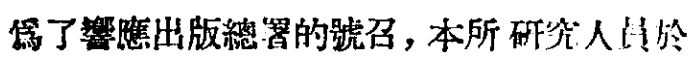

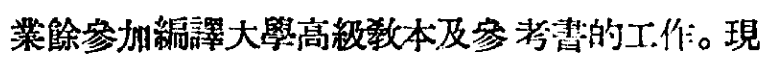
正進行精譯的有下列各書:

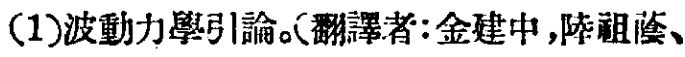
詐喿、㻡龍涐)

（2)近代物理(翻譯者:踐三强、何澤慧、金建 中、陵祖落、許喿、㛫光中、係念玻)

(3)自然放射原質(翻譯者:鈛三强)

(係念謍) 